\title{
EFFECT OF SEED MOISTURE CONTENT AND STORAGE CONTAINER ON SEED VIABILITY AND VIGOUR OF SOYBEAN
}

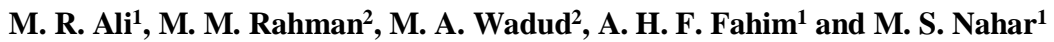 \\ ${ }^{1}$ Spices Research Centre, BARI, Shibganj, Bogura \\ ${ }^{2}$ Department of Agronomy, Bangladesh Agricultural University, Mymensingh \\ ${ }^{1}$ Spices Research Centre, BARI, Shibganj, Bogura \\ *Corresponding author, E-mail: rajabag68@yahoo.com
}

(Received: 13 August 2018, Accepted: 16 September 2018)

Keywords: Soybean, seed moisture, storage container, viability, vigour

\begin{abstract}
Soybean (Glycine max) seed loses its viability in the storage which causes shortage in supply of quality seed and consequently hinders the expansion of soybean cultivation in Bangladesh.Losses of seed viability of soybean (Glycine max) in traditional storage is very common in the tropical environment. An experiment was conducted at the Seed Laboratory, Regional Agricultural Research Station, Bangladesh Agricultural Research Institute (BARI), Jamalpur in 2011 and 2012 to find out the effect of seed moisture content and types of storage container on soybean seed germination and seedling vigour. In 2011, soybean seed having 94\% initial germination was stored at 8, 10 and $12 \%$ moisture levels but in 2012 seeds having $96 \%$ initial germination was stored at 6 , 8,10 and $12 \%$ initial moisture levels in four different types of storage containers viz., polythene bag, plastic pot, tin can and glass jar. weredays after storage ().The experiment was arranged in a factorial completely randomized design with three replications. In 2011, high germination of soybean seed (77-85\%) was retained at 200 DAS for those stored at $8 \%$ initial seed moisture content (SMC) in any of the containers. Germination index and seedling dry matter decreased with increased initial seed moisture content irrespective of storage containers used. Tin preserved higher seed moisture contents of $9.93,11.71$ and $14.15 \%$ for seed stored at $8 \%, 10 \%$ and $12 \%$ initial seed moisture content, respectively. In 2012, 80-94\% seed germination was retained at 200 DAS for those stored at $6 \%$ initial SMC in any of the containers. The germination declined to a range between 75.0 and $91.3 \%$ within 200 DAS at $8 \%$ initial SMC while those stored at $12 \%$ SMC showed rapid germination loss and the value showed down to between 9.3 and $22.0 \%$. Vigour index and seedling dry matter decreased with increased initial seed moisture content irrespective of storage containers used. Tin also Seeds stored in tin container showed the higher final seed moisture contents irrespective of initial seed moisture content.
\end{abstract}

\section{Introduction}

Seed is a living entry and is subjected to various stresses which affect the quality. In storage, the viability and vigour of the seeds not only vary from genera to genera and variety to variety, but it is also regulated by many physico-chemical factors like moisture content, atmospheric relative humidity, temperature, initial seed quality, physical and chemical composition of seed, gaseous exchange, storage structure, packaging materials, etc. In order to prevent the quantitative and qualitative losses due to several biotic and abiotic factors during storage, several methods are being adopted, such as seed treatment with suitable chemicals or plant products and storing in safe containers, besides sanitation of the storage place. To combat these factors effectively, 
storing the seeds in vapour proof containers like polythene bag, aluminum foils, tins or any sealed containers is found to be more useful in maintaining the desired quality of seeds for longer period, unlike those stored in moisture pervious containers like cloth bag and gunny bag. Arunnandhy and Senanayaka (1991) reported that the soybean seeds can be kept with high germination and vigour for more than one year when stored in sealed containers.

Storage containers or packaging materials are considered as one of the most important factors influencing longevity of seeds in storage. Many factors determine the longevity of seeds during storage. These includes seed moisture content, temperature, relative humidity, initial viability, stage of maturity at harvest, storage gas and initial moisture content of seed entering into storage (Tatipata, 2009). The farmers depend on their previous harvest for seeds and accordingly they preserve some portion of their harvest by indigenous methods. Generally low cost and easily available materials like earthen jar, coalter coated earthen jar, biscuit tin, kerosene tin, metal dram, gunny bag, polythene bag, dole, cow dung coated dole etc. are used as storage containers (Hossain, 1978). The farmers have different types of storage containers in order to protect the seed from moisture absorption and insect infestation. Storage container had significant effect on moisture content of wheat seed at different observation date of storing (Rahman et al., 2010). Seeds packed in polythene maintained high viability with time due to minimized moisture fluctuation and consequently produced more vigorous seedlings compared with those from seeds stored in jute or cloth bags which had little protection against moisture fluctuation (Karim et al., 2005). Starchy seeds above $12 \%$ moisture and oily seeds above $9 \%$ moisture should not be packed in moisture resistant containers. If seed could be packaged in moisture proof containers so that the relative humidity of the air around the seed remains low, then the seed equilibrium moisture remains low and the seed maintains its viability and vigour for a longer time (Poonam et al., 2001; Agha et al., 2004). The physical properties and storage potential of seed were influenced to a very large extent by moisture content and the relative humidity of the atmosphere surrounding the seed (Kong et al., 2008). Poor storage conditions greatly affect seed vigor (Simic et al., 2007). Clay pots and gunny bags showed an increase in moisture content and sharp decline seed viability within a year of storage than air tight tin cans and air tight glass jar (Naznin, 2005). In sealed containers, dry seeds can not absorb moisture from the external atmosphere (Karim et al., 2005). Krishnappa et al. (2002) found that groundnut seed stored in polyvinyl bag at $7 \%$ moisture content should the highest germination. Reports are also available that polythene bags can be used as moisture proof container (Alam and Rahman, 2005). Adequate dried seeds in sealed containers usually live longer at a given temperature than similar seeds in open containers. Soybean seeds stored in moisture proof containers retain high viability than those in moisture permeable containers (Tatipata, 2009).

Use of proper storage container to maintain the quality of farmers stored seed and preserving the seed viability should be an important consideration to reduce seed loss and increase crop yield (Samajpati et al., 1978). In view of the above facts, the present study was undertaken to determine appropriate moisture content for seed storage and storage container for reducing the loss of soybean seed viability. .

\section{Materials and Methods}

An experiment was conducted at Regional Agricultural Research Station Farm, Jamalpur during the period from May to December 2011 and 2012 with a view to study the effect of storage container and initial seed moisture content on germination and vigour of soybean seed. Soybean variety Shohag (PB1) collected from Bangladesh Agricultural Research Institute (BARI), Joydebpur, Gazipur. The crop was grown with proper agronomic management. The crop was harvested at full maturity and after proper processing, cleaning and drying the seed was stored in polythene bags until used for experimentation. The seed was dried in the sun on a triple set on the cemented floor to about $8 \%$ seed moisture content (SMC) in the $1^{\text {st }}$ year and $6.5 \%$ SMC in 
the $2^{\text {nd }}$ year. Just before final storage the seed was re-hydrated at $70 \% \mathrm{RH}$ for required period of time to obtain target moisture content of 8,10 and $12 \%$ for the $1^{\text {st }}$ year and $6.50,8,10$ and $12 \%$ for $2^{\text {nd }}$ year. Four types of storage containers viz., polythene bag, plastic pot, tin can and glass jar were used in the experiment. The seed $(500 \mathrm{~g})$ was stored in the respective containers on 14 May 2011 and 18 May 2012 respectively. Each container was completely filled with seed as per experimental specification and then made air tight. The experiment was arranged in a factorial completely randomized design with three replicates. The seed was tested for different quality parameters at 40, 80, 120, 160 and 200 days after storage (DAS). The containers were kept in the laboratory under ambient room condition. The quality parameters tested were seed moisture content, germination percentage, vigour index, and seedling dry matter.

Seed moisture content was measured using high constant temperature oven dry method following ISTA rules (1999). About 5-8g of seeds were taken in the aluminum dish and dried in the oven at $130{ }^{\circ} \mathrm{C}$ for 2 hours (until constant weight reached). Then the moisture content was calculated as follows:

Where,

$$
\text { Moisture content }(\%)=\frac{\mathrm{W}_{1}-\mathrm{W}}{---------\times 100}
$$

$\mathrm{W}=$ Weight of blank aluminum dish with lid

$\mathrm{W}_{1}=$ Weight of seed plus aluminum dish with lid before drying

$\mathrm{W}_{2}=$ Weight of seed plus aluminum dish with lid after drying

\section{Germination percentage}

Germination test was done in sand culture method. Two third of a plastic dish $(20 \mathrm{~cm}$ diameter and $15 \mathrm{~cm}$ deep) was filled with sterilized sand having $60 \%$ water holding capacity. Randomly collected 100 seeds from each container were placed into the sand for the germination test. The germination dishes were placed in the germination cabinet and seedling evaluation was done at 8 days after placing the test. The number of normal seedlings per dish was regarded as the germination percentage.

\section{Germination index (GI)}

Germination index of seed was estimated from the seed set in the germination test by calculating the germination index following the formula below given by Association of Official Seed Analysts. The number of seedling was counted at each day at the same time from the day after seed set until the last count was made. The seedling emerged each day having plumule length of $2 \mathrm{~cm}$ or more was considered as germinated.

Germination index $=\frac{\text { No.ofseedlingat } 1 \text { stcount }}{\text { Daystolstcount }}+---+\frac{\text { No.ofseedlingatfinalcount }}{\text { Daystofinalcount }}$

\section{Seedling dry matter}

The normal seedlings from each germination dish was collected and washed with running tap water and surface dried. Then the seedling was dried in the oven at $70{ }^{\circ} \mathrm{C}$ temperature for 48 hours (until constant weight reached).

Data analysis was done statistically following the analysis of variance (ANOVA) technique and the means were compared by Duncan's Multiple Range Test (Gomez and Gomez, 1984).

\section{Results and Discussion}

\section{Seed moisture content (SMC)}


Storage container and initial seed moisture content had significant effect on final seed moisture content of soybean seed at 40, 80, 120, 160 and 200 DAS in 2011 and 2012 (Table 1). In 2011, the lowest seed moisture content of seeds stored in glass jar at 8\% initial SMC were 8.08, 8.21, $8.31,8.51$ and $8.73 \%$ at $40,80,120,160$ and 200 DAS, respectively and percent moisture increased 1.00, 2.63, 3.87, 6.37 and 9.12\% while the highest seed moisture content was observed from those seeds stored in metallic can at 12\% initial SMC were 12.64, 13.08, 13.51, 13.87 and $14.15 \%$ at $40,80,120,160$ and 200 DAS, respectively and \% moisture increased $5.33,9.00,12.58,15.58$ and $17.92 \%$ (Table 1). This result are in agreement with the findings of Naznin (2005) who reported that air tight tin can showed an increase in moisture content and sharp decline seed viability within a year of storage than air tight glass jar. In 2012, the lowest seed moisture content of seeds stored in glass jar at 6\% initial SMC were 6.57, 6.61, 6.83, 7.12 and $7.38 \%$ at $40,80,120,160$ and 200 DAS, respectively and percent moisture increased 0.87 , $1.83,5.50,10.33$ and $14.67 \%$ while the highest seed moisture content was observed from those seeds stored in metallic can at $12 \%$ initial SMC were 12.40, 12.66, 13.02, 13.45 and $13.85 \%$ at 40, 80, 120, 160 and 200 DAS, respectively and \% moisture increased 3.33, 5.50, 8.05, 12.08 and $15.42 \%$ (Table 1).

\section{Germination percentage}

Storage container and initial seed moisture content had significant effect on final seed moisture content of soybean seed at 40, 80, 120, 160 and 200 DAS in 2011 and 2012 (Table 1). In 2011, the lowest seed moisture content of seeds stored in glass jar at $8 \%$ initial SMC were 8.08, 8.21, $8.31,8.51$ and $8.73 \%$ at $40,80,120,160$ and 200 DAS, respectively and percent moisture increased $1.00,2.63,3.87,6.37$ and $9.125 \%$ while the highest seed moisture content was observed from those seeds stored in metalic can at 12\% initial SMC were 12.64, 13.08, 13.51, 13.87 and $14.15 \%$ at 40, 80, 120, 160 and 200 DAS, respectively and percent moisture increased 5.33, 9.00, 12.58, 15.58 and $17.92 \%$ (Table 2). This result are in agreement with the findings of Naznin (2005) who reported that air tight tin can showed an increase in moisture content and sharp decline seed viability within a year of storage than air tight glass jar. In 2012, the lowest seed moisture content of seeds stored in glass jar at 6\% initial SMC were 6.57, 6.61, $6.83,7.12$ and $7.38 \%$ at $40,80,120,160$ and 200 DAS, respectively and percent moisture increased $0.87,1.83,5.50,10.33$ and $14.67 \%$ while the highest seed moisture content was observed from those seeds stored in metalic can at 12\% initial SMC were 12.40, 12.66, 13.02, 13.45 and $13.85 \%$ at $40,80,120,160$ and 200 DAS, respectively and percent moisture increased 3.33, 5.50, 8.05, 12.08 and $15.42 \%$ (Table 2).

\section{Germination index}

The interaction effect of initial seed moisture content and storage container on germination index was statistically significant at each of the observation dates during the storage period both in 2011 and 2012. The interaction of glass jars with 8\% initial SMC showed higher germination index than metallic can container with $12 \%$ initial SMC at each of the observation dates for both the years. In 2011, the germination index of seeds kept in glass jar with $8 \%$ initial SMC were 25.41, 21.26, 17.53, 14.15 and 10.44 at 40, 80, 120, 160 and 200 DAS, respectively and it was statistically similar to $8 \%$ initial SMC in polythene bag and plastic pot at each of the observation dates and those seeds stored in metatlic can container with $12 \%$ SMC were 2.11 and 0.09 at 40 and $80 \mathrm{DAS}$, respectively. Those seeds stored in metallic can, plastic pot and polythene bag with $12 \%$ initial SMC completely lost viability at 120 DAS and no seedling was found (Table 3). In 2012, the germination index of seeds kept in glass jar with $6 \%$ initial SMC were $30.69,29.22,25.32,21.76$ and 12.58 at 40, 80, 120, 160 and 200 DAS, respectively and it was statistically similar to those seeds stored in polythene bag and plastic pot with $6 \%$ and $8 \%$ initial SMC. The corresponding values for seeds stored in metallic can container with $12 \%$ initial SMC were 20.85, 16.49, 10.48, 3.61 and 0.60 at 40, 80, 120, 160 and 200 DAS, respectively (Table 3 ). 


\section{Seedling dry matter}

The interaction of initial seed moisture content and storage container had significant effect of on seedling dry matter at each of the observation dates during the storage in 2011 and 2012. The interaction effect of glass jar with $8 \%$ initial SMC showed higher seedling dry matter than metalic can container with $12 \%$ initial SMC at each of the observation dates for both the years. In 2011 , the seedling dry matter of seeds in glass jar with $8 \%$ initial SMC were $0.127,0.124$, $0.122,0.117$ and $0.112 \mathrm{~g}$ seedling $^{-1}$ at 40, 80, 120, 160 and 200 DAS while those values for seeds stored in metallic can container with $12 \%$ initial SMC were 0.078 and $0.076 \mathrm{~g}^{2}$ seedling ${ }^{-1}$ at 40 and 80 DAS, respectively. Seeds with $12 \%$ initial SMC stored in metalic can, plastic pot and polythene bag completely lost viability at 120 DAS and no seedling was found (Table 4). In 2012, the seedling dry matter of seeds in glass jar with 6\% SMC were $0.116,0.112,0.108$, 0.106 and $0.101 \mathrm{~g}$ seedling $^{-1}$ at 40,80,120,160 and 200 DAS while those values for seeds stored in metallic can container with $12 \%$ initial SMC were $0.086,0.084,0.080$ and $0.077 \mathrm{~g}$ seedling $^{-1}$ at 40, 80, 120 and 160 DAS, respectively and it was statistically at par to plastic pot and polythene bag with $12 \%$ initial SMC. Those seeds stored in metalic can, polythene bag and plastic pot with $12 \%$ initial SMC completely lost viability at 200 DAS and no seedling emergence was found (Table 4). 
Table 1. Interaction effect of initial seed moisture content and storage container on final seed moisture content of soybean seed at different days after storage (DAS) storage in 2011 and 2012

\begin{tabular}{|c|c|c|c|c|c|c|c|c|c|c|}
\hline \multirow{3}{*}{$\begin{array}{l}\text { Initial SMC } \\
\times \text { container }\end{array}$} & \multicolumn{10}{|c|}{ Seed moisture content $(\%)$} \\
\hline & \multicolumn{5}{|c|}{2011} & \multicolumn{5}{|c|}{2012} \\
\hline & $40 \mathrm{DAS}$ & $80 \mathrm{DAS}$ & $120 \mathrm{DAS}$ & $160 \mathrm{DAS}$ & $200 \mathrm{DAS}$ & $40 \mathrm{DAS}$ & 80 DAS & $120 \mathrm{DAS}$ & $160 \mathrm{DAS}$ & $200 \mathrm{DAS}$ \\
\hline $\mathrm{M}_{1} \mathrm{C}_{1}$ & - & - & - & - & - & $6.58 \mathrm{~d}$ & $6.72 \mathrm{i}$ & 6.891 & $7.29 \mathrm{e}$ & $7.85 \mathrm{gh}$ \\
\hline $\mathrm{M}_{1} \mathrm{C}_{2}$ & - & - & - & - & - & $6.59 \mathrm{~d}$ & $6.75 \mathrm{i}$ & $6.99 \mathrm{k}$ & $7.32 \mathrm{e}$ & $7.78 \mathrm{gh}$ \\
\hline $\mathrm{M}_{1} \mathrm{C}_{3}$ & - & - & - & - & - & $6.68 \mathrm{~d}$ & $6.93 \mathrm{~h}$ & $7.25 \mathrm{j}$ & $7.77 \mathrm{de}$ & $8.23 f g$ \\
\hline $\mathrm{M}_{1} \mathrm{C}_{4}$ & - & - & - & - & - & $6.57 \mathrm{~d}$ & $6.61 \mathrm{j}$ & $6.83 \mathrm{~m}$ & $7.12 \mathrm{e}$ & $7.38 \mathrm{~h}$ \\
\hline $\mathrm{M}_{2} \mathrm{C}_{1}$ & $8.15 \mathrm{~g}$ & $8.42 \mathrm{~h}$ & $8.58 \mathrm{~h}$ & $8.87 \mathrm{j}$ & $9.12 \mathrm{j}$ & $8.14 \mathrm{c}$ & $8.44 \mathrm{~h}$ & $8.66 \mathrm{~h}$ & $8.87 \mathrm{~d}-\mathrm{e}$ & $9.09 \mathrm{e}$ \\
\hline $\mathrm{M}_{2} \mathrm{C}_{2}$ & $8.15 \mathrm{~g}$ & $8.30 \mathrm{i}$ & $8.46 \mathrm{~h}$ & $8.70 \mathrm{k}$ & $8.92 \mathrm{k}$ & $8.11 \mathrm{c}$ & $8.24 \mathrm{~g}$ & $8.36 \mathrm{i}$ & $8.49 \mathrm{cde}$ & $8.80 \mathrm{e}$ \\
\hline $\mathrm{M}_{2} \mathrm{C}_{3}$ & $8.33 \mathrm{f}$ & $8.73 \mathrm{~g}$ & $9.18 \mathrm{~g}$ & $9.46 \mathrm{i}$ & $9.93 i$ & $8.19 \mathrm{c}$ & $8.42 \mathrm{f}$ & $8.84 \mathrm{~g}$ & $9.14 \mathrm{~b}-\mathrm{e}$ & $9.69 \mathrm{~d}$ \\
\hline $\mathrm{M}_{2} \mathrm{C}_{4}$ & $8.08 \mathrm{~g}$ & $8.21 \mathrm{i}$ & $8.31 \mathrm{~h}$ & 8.511 & 8.731 & $8.10 \mathrm{c}$ & $8.22 \mathrm{~g}$ & $8.35 \mathrm{i}$ & $8.50 \mathrm{cde}$ & $8.70 \mathrm{ef}$ \\
\hline $\mathrm{M}_{3} \mathrm{C}_{1}$ & $10.20 \mathrm{e}$ & $10.46 \mathrm{e}$ & $10.77 \mathrm{e}$ & $11.06 \mathrm{f}$ & $11.42 \mathrm{f}$ & $10.39 \mathrm{~b}$ & $10.60 \mathrm{~d}$ & $10.92 d$ & $11.24 \mathrm{ab}$ & $11.64 \mathrm{~b}$ \\
\hline $\mathrm{M}_{3} \mathrm{C}_{2}$ & $10.14 \mathrm{e}$ & $10.38 \mathrm{ef}$ & $10.63 \mathrm{ef}$ & $10.94 \mathrm{~g}$ & $11.25 \mathrm{~g}$ & $10.34 \mathrm{bb}$ & $10.56 \mathrm{~d}$ & $10.78 \mathrm{e}$ & $11.12 \mathrm{ab}$ & $11.59 \mathrm{~b}$ \\
\hline $\mathrm{M}_{3} \mathrm{C}_{3}$ & $10.49 \mathrm{~d}$ & $10.75 \mathrm{~d}$ & $11.33 \mathrm{~g}$ & $11.34 \mathrm{e}$ & $11.71 \mathrm{e}$ & $10.31 \mathrm{~b}$ & $10.57 \mathrm{~d}$ & $10.89 \mathrm{~d}$ & $11.23 \mathrm{ab}$ & $11.77 \mathrm{~b}$ \\
\hline $\mathrm{M}_{3} \mathrm{C}_{4}$ & $10.07 \mathrm{e}$ & $10.32 \mathrm{f}$ & $10.42 \mathrm{f}$ & $10.61 \mathrm{~h}$ & $10.90 \mathrm{~h}$ & $10.21 \mathrm{~b}$ & $10.32 \mathrm{e}$ & $10.45 \mathrm{f}$ & $10.61 b c$ & $10.90 \mathrm{c}$ \\
\hline $\mathrm{M}_{4} \mathrm{C}_{1}$ & $12.27 \mathrm{~b}$ & $12.61 \mathrm{~b}$ & $12.86 \mathrm{~b}$ & $13.11 \mathrm{~b}$ & $13.40 \mathrm{~b}$ & $12.38 \mathrm{a}$ & $12.5 \mathrm{~b} 8$ & $12.92 \mathrm{~b}$ & $13.31 \mathrm{bcd}$ & $13.67 \mathrm{a}$ \\
\hline $\mathrm{M}_{4} \mathrm{C}_{2}$ & $12.20 \mathrm{bc}$ & $12.43 \mathrm{c}$ & $12.75 b$ & $12.90 \mathrm{c}$ & $13.14 \mathrm{c}$ & $12.35 \mathrm{a}$ & $12.46 \mathrm{c}$ & $12.80 \mathrm{c}$ & $13.15 \mathrm{a}$ & $13.62 \mathrm{a}$ \\
\hline $\mathrm{M}_{4} \mathrm{C}_{3}$ & $12.64 \mathrm{a}$ & $13.08 \mathrm{a}$ & $13.51 \mathrm{a}$ & $13.87 \mathrm{a}$ & $14.15 \mathrm{a}$ & $12.40 \mathrm{a}$ & $12.66 \mathrm{a}$ & $13.02 \mathrm{a}$ & $13.45 \mathrm{a}$ & $13.85 \mathrm{a}$ \\
\hline $\mathrm{M}_{4} \mathrm{C}_{4}$ & $12.11 \mathrm{c}$ & $12.34 \mathrm{c}$ & $12.45 \mathrm{c}$ & $12.62 \mathrm{~d}$ & $12.83 \mathrm{~d}$ & $12.33 \mathrm{a}$ & $12.56 \mathrm{~b}$ & $12.79 \mathrm{c}$ & $13.10 \mathrm{a}$ & $13.51 \mathrm{a}$ \\
\hline $\mathrm{CV}(\%)$ & 6.79 & 5.70 & 4.45 & 8.49 & 7.51 & 5.93 & 7.40 & 6.27 & 4.20 & 7.71 \\
\hline
\end{tabular}

In a column, values having similar letter(s) do not differ significantly by DMRT

Note: $\mathrm{C}_{1}=$ Polythene bag, $\mathrm{C}_{2}=$ Plastic pot, $\mathrm{C}_{3}=$ Metalic can, $\mathrm{C}_{4}=$ Glass jar, $\mathrm{M}_{1}=6.5 \mathrm{MC}, \mathrm{M}_{2}=8 \% \mathrm{SMC}, \mathrm{M}_{3}=10 \% \mathrm{SMC}, \mathrm{M}_{4}=12 \% \mathrm{SMC}$ 
Table 2. Interaction effect of initial seed moisture content and storage container on germination and field emergence of soybean seed at different DAS in 2011 and 2012

\begin{tabular}{|c|c|c|c|c|c|c|c|c|c|c|}
\hline \multirow{3}{*}{$\begin{array}{l}\text { Initial SMC } \\
\text { xcontainer }\end{array}$} & \multicolumn{10}{|c|}{ Germination (\%) } \\
\hline & \multicolumn{5}{|c|}{2011} & \multicolumn{5}{|c|}{2012} \\
\hline & $40 \mathrm{DAS}$ & 80 DAS & $120 \mathrm{DAS}$ & $160 \mathrm{DAS}$ & $200 \mathrm{DAS}$ & 40 DAS & $80 \mathrm{DAS}$ & $120 \mathrm{DAS}$ & $160 \mathrm{DAS}$ & $200 \mathrm{DAS}$ \\
\hline $\mathrm{M}_{1} \mathrm{C}_{1}$ & - & - & - & - & - & $94.7 \mathrm{abc}$ & $93.3 \mathrm{a}-\mathrm{e}$ & $92.7 \mathrm{ab}$ & $90.7 \mathrm{abc}$ & $90.0 \mathrm{a}$ \\
\hline $\mathrm{M}_{1} \mathrm{C}_{2}$ & - & - & - & - & - & $97.3 \mathrm{a}$ & $96.0 \mathrm{ab}$ & $93.3 \mathrm{ab}$ & $92.7 \mathrm{ab}$ & $91.3 \mathrm{a}$ \\
\hline $\mathrm{M}_{1} \mathrm{C}_{3}$ & - & - & - & - & - & $91.3 \mathrm{a}-\mathrm{d}$ & $90.0 \mathrm{~b}-\mathrm{e}$ & $88.0 \mathrm{bc}$ & $85.3 \mathrm{bc}$ & $80.0 \mathrm{~b}$ \\
\hline $\mathrm{M}_{1} \mathrm{C}_{4}$ & - & - & - & - & - & $97.3 \mathrm{a}$ & $96.7 \mathrm{a}$ & $96.0 \mathrm{a}$ & $95.3 \mathrm{a}$ & $94.0 \mathrm{a}$ \\
\hline $\mathrm{M}_{2} \mathrm{C}_{1}$ & $89.7 \mathrm{ab}$ & $88.0 \mathrm{ab}$ & $86.0 \mathrm{ab}$ & $83.3 \mathrm{ab}$ & $80.0 \mathrm{ab}$ & $94.00 \mathrm{abc}$ & $94.7 \mathrm{abc}$ & $93.3 \mathrm{ab}$ & $91.33 \mathrm{abc}$ & $90.3 \mathrm{a}$ \\
\hline $\mathrm{M}_{2} \mathrm{C}_{2}$ & $90.0 \mathrm{ab}$ & $89.0 \mathrm{a}$ & $87.0 \mathrm{ab}$ & $84.7 \mathrm{ab}$ & $82.3 \mathrm{ab}$ & $94.7 \mathrm{abc}$ & $94.0 \mathrm{a}-\mathrm{d}$ & $92.7 \mathrm{ab}$ & $92.0 \mathrm{abc}$ & $90.7 \mathrm{a}$ \\
\hline $\mathrm{M}_{2} \mathrm{C}_{3}$ & $86.0 \mathrm{ab}$ & $84.3 \mathrm{abc}$ & 81.0bcd & $79.3 b c$ & $77.3 \mathrm{bc}$ & $88.7 \mathrm{~cd}$ & 88.0de & $85.3 \mathrm{c}$ & $84.7 \mathrm{c}$ & $75.0 \mathrm{~b}$ \\
\hline $\mathrm{M}_{2} \mathrm{C}_{4}$ & $91.7 \mathrm{a}$ & $90.7 \mathrm{a}$ & $89.0 \mathrm{a}$ & $87.0 \mathrm{a}$ & $85.0 \mathrm{a}$ & $95.3 \mathrm{ab}$ & $94.0 \mathrm{a}-\mathrm{d}$ & $93.3 \mathrm{ab}$ & $92.7 \mathrm{ab}$ & $91.3 \mathrm{a}$ \\
\hline $\mathrm{M}_{3} \mathrm{C}_{1}$ & $84.3 b$ & $78.7 \mathrm{c}$ & $55.0 \mathrm{~d}$ & $71.0 \mathrm{~d}$ & $68.0 \mathrm{~d}$ & $88.7 \mathrm{~cd}$ & $91.3 \mathrm{a}-\mathrm{e}$ & $69.33 d$ & $55.3 \mathrm{de}$ & $44.7 \mathrm{c}$ \\
\hline $\mathrm{M}_{3} \mathrm{C}_{2}$ & $85.3 b$ & $81.3 b c$ & $76.7 \mathrm{~cd}$ & $74.0 \mathrm{~cd}$ & $72.7 \mathrm{~cd}$ & $94.0 \mathrm{abc}$ & $88.7 \mathrm{cde}$ & $65.3 \mathrm{de}$ & $47.3 \mathrm{f}$ & $42.0 \mathrm{c}$ \\
\hline $\mathrm{M}_{3} \mathrm{C}_{3}$ & $75.7 \mathrm{c}$ & $70.3 \mathrm{~d}$ & $63.3 \mathrm{e}$ & $58.3 \mathrm{e}$ & $52.7 \mathrm{e}$ & $88.7 \mathrm{~cd}$ & $87.3 \mathrm{e}$ & $50.0 \mathrm{f}$ & $48.7 \mathrm{cf}$ & $46.7 \mathrm{c}$ \\
\hline $\mathrm{M}_{3} \mathrm{C}_{4}$ & $87.3 \mathrm{ab}$ & $84.7 \mathrm{abc}$ & $82.3 b c$ & $83.3 \mathrm{ab}$ & $78.3 b$ & $91.3 \mathrm{a}-\mathrm{d}$ & $90.7 \mathrm{a}-\mathrm{e}$ & $59.3 \mathrm{e}$ & $57.3 \mathrm{~d}$ & $54.0 \mathrm{c}$ \\
\hline $\mathrm{M}_{4} \mathrm{C}_{1}$ & $24.7 \mathrm{f}$ & $6.7 \mathrm{f}$ & $0.0 \mathrm{~g}$ & $0.0 \mathrm{~g}$ & $0.0 \mathrm{~g}$ & $86.0 \mathrm{~d}$ & 72.0fg & $52.0 \mathrm{f}$ & $26.0 \mathrm{~g}$ & $10.7 \mathrm{~d}$ \\
\hline $\mathrm{M}_{4} \mathrm{C}_{2}$ & $37.3 \mathrm{e}$ & $9.3 \mathrm{f}$ & $0.0 \mathrm{~g}$ & $0.0 \mathrm{~g}$ & $0.0 \mathrm{~g}$ & $88.7 \mathrm{~cd}$ & $72.7 f$ & $50.0 \mathrm{f}$ & $24.7 \mathrm{~g}$ & $10.0 \mathrm{~d}$ \\
\hline $\mathrm{M}_{4} \mathrm{C}_{3}$ & $19.3 \mathrm{~g}$ & $2.7 \mathrm{f}$ & $0.0 \mathrm{~g}$ & $0.0 \mathrm{~g}$ & $0.0 \mathrm{~g}$ & 75.0fg & $66.0 \mathrm{~g}$ & $40.0 \mathrm{~g}$ & $16.7 \mathrm{~h}$ & $9.3 \mathrm{~d}$ \\
\hline $\mathrm{M}_{4} \mathrm{C}_{4}$ & $58.3 \mathrm{~d}$ & $46.7 \mathrm{e}$ & $37.0 \mathrm{f}$ & 29.0f & 21.0f & $89.3 \mathrm{bcd}$ & $70.7 \mathrm{fg}$ & $41.3 \mathrm{~g}$ & $24.0 \mathrm{gh}$ & $22.0 \mathrm{~d}$ \\
\hline $\mathrm{CV}(\%)$ & 4.46 & 6.58 & 6.12 & 6.25 & 6.16 & 4.82 & 5.27 & 5.29 & 7.08 & 9.76 \\
\hline
\end{tabular}

DAS= Days after sowing,

In a column, values having similar letter(s) do not differ significantly by DMRT

Note: $\mathrm{C}_{1}=$ Polythene bag, $\mathrm{C}_{2}=$ Plastic pot, $\mathrm{C}_{3}=$ Metallic can, $\mathrm{C}_{4}=$ Glass jar, $\mathrm{M}_{1}=6 \% \mathrm{SMC}, \mathrm{M}_{2}=8 \% \quad \mathrm{SMC}, \mathrm{M}_{3}=10 \% \quad \mathrm{SMC}, \mathrm{M}_{4}=12 \% \mathrm{SMC}$ 
Table 3. Interaction effect of initial seed moisture content and storage container on germination index of soybean seed at DAS storage in 2011 and 2012

\begin{tabular}{|c|c|c|c|c|c|c|c|c|c|c|}
\hline \multirow{3}{*}{$\begin{array}{l}\text { Initial SMC } \\
\text { xcontainer }\end{array}$} & \multicolumn{10}{|c|}{ Germination index } \\
\hline & \multicolumn{5}{|c|}{2011} & \multicolumn{5}{|c|}{2012} \\
\hline & $40 \mathrm{DAS}$ & $80 \mathrm{DAS}$ & $120 \mathrm{DAS}$ & 160 DAS & 200 DAS & $40 \mathrm{DAS}$ & $80 \mathrm{DAS}$ & $120 \mathrm{DAS}$ & 160 DAS & $200 \mathrm{DAS}$ \\
\hline $\mathrm{M}_{1} \mathrm{C}_{1}$ & - & - & - & - & - & $29.01 \mathrm{abc}$ & $28.95 \mathrm{a}$ & $24.29 \mathrm{ab}$ & $21.44 \mathrm{a}$ & $12.05 \mathrm{a}$ \\
\hline $\mathrm{M}_{1} \mathrm{C}_{2}$ & - & - & - & - & - & $29.74 a b c$ & $28.98 \mathrm{a}$ & $21.52 \mathrm{a}-\mathrm{d}$ & $19.85 \mathrm{ab}$ & $11.88 \mathrm{a}$ \\
\hline $\mathrm{M}_{1} \mathrm{C}_{3}$ & - & - & - & - & - & 28.11a-e & $26.41 b c$ & $18.04 d-h$ & $15.73 \mathrm{~cd}$ & $9.27 \mathrm{~b}$ \\
\hline $\mathrm{M}_{1} \mathrm{C}_{4}$ & - & - & - & - & - & $30.69 \mathrm{a}$ & $29.22 \mathrm{a}$ & $25.32 \mathrm{a}$ & $21.76 \mathrm{a}$ & $12.58 \mathrm{a}$ \\
\hline $\mathrm{M}_{2} \mathrm{C}_{1}$ & $25.22 \mathrm{a}$ & $20.75 a b$ & $16.13 \mathrm{ab}$ & $13.27 \mathrm{~b}$ & $9.89 \mathrm{ab}$ & $28.34 \mathrm{a}-\mathrm{d}$ & $27.15 \mathrm{ab}$ & $21.43 a-d$ & $20.25 \mathrm{ab}$ & $10.12 \mathrm{ab}$ \\
\hline $\mathrm{M}_{2} \mathrm{C}_{2}$ & $24.41 \mathrm{a}$ & $22.00 \mathrm{a}$ & $16.95 \mathrm{ab}$ & $13.78 \mathrm{ab}$ & $10.23 \mathrm{a}$ & $28.92 \mathrm{a}-\mathrm{d}$ & $28.55 \mathrm{a}$ & $20.67 a-f$ & $18.27 \mathrm{a}$ & $10.56 \mathrm{a}$ \\
\hline $\mathrm{M}_{2} \mathrm{C}_{3}$ & $23.35 \mathrm{ab}$ & $20.25 \mathrm{ab}$ & $15.21 \mathrm{~b}$ & $11.46 \mathrm{c}$ & $9.13 b$ & $26.50 \mathrm{cde}$ & $23.21 \mathrm{~d}$ & $16.64 \mathrm{e}-\mathrm{h}$ & $15.79 \mathrm{~cd}$ & $8.57 \mathrm{~b}$ \\
\hline $\mathrm{M}_{2} \mathrm{C}_{4}$ & $25.41 \mathrm{a}$ & $21.26 a b$ & $17.53 \mathrm{a}$ & $14.15 \mathrm{a}$ & $10.44 \mathrm{a}$ & $29.28 \mathrm{ab}$ & $28.69 a$ & $23.00 \mathrm{abc}$ & $21.60 \mathrm{a}$ & $10.30 \mathrm{ab}$ \\
\hline $\mathrm{M}_{3} \mathrm{C}_{1}$ & $22.80 \mathrm{ab}$ & $17.00 \mathrm{c}$ & $11.40 \mathrm{c}$ & $8.62 \mathrm{e}$ & $7.48 \mathrm{c}$ & $25.85 \mathrm{de}$ & $24.13 d$ & $20.41 \mathrm{~d}-\mathrm{g}$ & $13.27 \mathrm{de}$ & $4.05 \mathrm{cde}$ \\
\hline $\mathrm{M}_{3} \mathrm{C}_{2}$ & $23.12 \mathrm{ab}$ & $17.41 \mathrm{c}$ & $12.05 \mathrm{c}$ & $8.90 \mathrm{e}$ & $7.58 \mathrm{c}$ & $27.92 b-e$ & $23.90 \mathrm{~d}$ & $19.40 c-h$ & $10.70 \mathrm{ef}$ & $3.58 \mathrm{cde}$ \\
\hline $\mathrm{M}_{3} \mathrm{C}_{3}$ & $20.70 \mathrm{~b}$ & $14.35 \mathrm{~d}$ & $7.64 d$ & $6.23 \mathrm{f}$ & $5.62 d$ & $27.90 \mathrm{~b}-\mathrm{e}$ & $20.62 \mathrm{e}$ & 11.63ij & $8.43 \mathrm{fg}$ & $5.57 \mathrm{bcd}$ \\
\hline $\mathrm{M}_{3} \mathrm{C}_{4}$ & $23.48 \mathrm{a}$ & $19.43 b$ & $12.92 \mathrm{c}$ & $9.66 \mathrm{~d}$ & $8.23 c$ & $29.23 \mathrm{ab}$ & $25.01 \mathrm{~cd}$ & $21.07 \mathrm{a}-\mathrm{e}$ & $13.27 \mathrm{de}$ & $5.64 \mathrm{bcd}$ \\
\hline $\mathrm{M}_{4} \mathrm{C}_{1}$ & $6.04 \mathrm{~d}$ & $0.64 \mathrm{f}$ & $0.00 \mathrm{f}$ & $0.00 \mathrm{f}$ & $0.00 \mathrm{f}$ & $21.84 \mathrm{df}$ & $19.84 \mathrm{e}$ & $15.83 \mathrm{ghi}$ & $8.75 f$ & $0.94 \mathrm{de}$ \\
\hline $\mathrm{M}_{4} \mathrm{C}_{2}$ & $6.01 \mathrm{~d}$ & $0.67 f$ & $0.00 \mathrm{f}$ & $0.00 \mathrm{f}$ & $0.00 \mathrm{f}$ & $25.54 \mathrm{e}$ & $19.72 \mathrm{e}$ & 15.07hij & $5.57 \mathrm{gh}$ & $095 \mathrm{e}$ \\
\hline $\mathrm{M}_{4} \mathrm{C}_{3}$ & $2.11 \mathrm{e}$ & $0.09 \mathrm{f}$ & $0.00 \mathrm{f}$ & $0.00 \mathrm{f}$ & $0.00 \mathrm{f}$ & $20.85 b-e$ & $16.49 \mathrm{f}$ & $10.48 \mathrm{j}$ & $3.61 \mathrm{~h}$ & $0.60 \mathrm{e}$ \\
\hline $\mathrm{M}_{4} \mathrm{C}_{4}$ & $10.44 \mathrm{c}$ & $9.83 \mathrm{e}$ & $4.39 \mathrm{e}$ & $2.50 \mathrm{~g}$ & $2.31 \mathrm{e}$ & $27.04 \mathrm{~b}-\mathrm{e}$ & $19.18 \mathrm{e}$ & $16.13 \mathrm{f}-\mathrm{i}$ & $9.80 \mathrm{f}$ & 8.01abc \\
\hline $\mathrm{CV}(\%)$ & 8.60 & 8.60 & 6.34 & 5.46 & 8.34 & 5.57 & 5.11 & 7.76 & 8.04 & 6.04 \\
\hline
\end{tabular}

DAS= Days after sowing,

In a column, values having similar letter(s) do not differ significantly by DMRT

Note: $\mathrm{C}_{1}=$ Polythene bag, $\mathrm{C}_{2}=$ Plastic pot, $\mathrm{C}_{3}=$ Metalic can, $\mathrm{C}_{4}=$ Glass jar, $\mathrm{M}_{1}=6 \% \mathrm{SMC}, \mathrm{M}_{2}=8 \% \mathrm{SMC}, \mathrm{M}_{3}=10 \% \mathrm{SMC}, \mathrm{M}_{4}=12 \% \mathrm{SMC}$ 
Table 4. Interaction effect of initial seed moisture content and storage container on seedling dry matter (g) of soybean at different DAS during storage in 2011 and 2012

\begin{tabular}{|c|c|c|c|c|c|c|c|c|c|c|}
\hline \multirow{3}{*}{$\begin{array}{l}\text { Initial SMC } \\
\text { xcontainer }\end{array}$} & \multicolumn{10}{|c|}{ Seedling dry matter $\left(\mathrm{g}\right.$ seedling $\left.{ }^{-1}\right)$} \\
\hline & \multicolumn{5}{|c|}{2011} & \multicolumn{5}{|c|}{2012} \\
\hline & 40 DAS & 80 DAS & $120 \mathrm{DAS}$ & 160 DAS & $200 \mathrm{DAS}$ & $40 \mathrm{DAS}$ & 80 DAS & 120 DAS & 160 DAS & 200 DAS \\
\hline $\mathrm{M}_{1} \mathrm{C}_{1}$ & - & - & - & - & - & $0.113 b$ & $0.111 \mathrm{a}$ & $0.104 \mathrm{ab}$ & $0.098 \mathrm{~d}$ & $0.093 \mathrm{c}$ \\
\hline $\mathrm{M}_{1} \mathrm{C}_{2}$ & - & - & - & - & - & $0.114 \mathrm{ab}$ & $0.107 b$ & $0.105 \mathrm{a}$ & $0.103 \mathrm{bc}$ & $0.099 b$ \\
\hline $\mathrm{M}_{1} \mathrm{C}_{3}$ & - & - & - & - & - & $0.095 b$ & $0.106 b$ & $0.101 \mathrm{abc}$ & $0.092 \mathrm{e}$ & $0.086 \mathrm{~d}$ \\
\hline $\mathrm{M}_{1} \mathrm{C}_{4}$ & - & - & - & - & - & $0.116 \mathrm{a}$ & $0.112 \mathrm{a}$ & $0.108 \mathrm{a}$ & $0.106 \mathrm{a}$ & $0.101 \mathrm{a}$ \\
\hline $\mathrm{M}_{2} \mathrm{C}_{1}$ & $0.112 b$ & $0.111 \mathrm{c}$ & $0.108 \mathrm{c}$ & $0.104 \mathrm{c}$ & $0.099 \mathrm{c}$ & $0.112 b$ & $0.110 \mathrm{ab}$ & $0.100 \mathrm{a}-\mathrm{d}$ & $0.086 f$ & $0.055 f$ \\
\hline $\mathrm{M}_{2} \mathrm{C}_{2}$ & $0.123 \mathrm{a}$ & $0.119 b$ & $0.116 \mathrm{~b}$ & $0.122 b$ & $0.106 b$ & $0.109 b$ & $0.104 c$ & $0.104 \mathrm{ab}$ & $0.101 \mathrm{c}$ & $0.088 \mathrm{~cd}$ \\
\hline $\mathrm{M}_{2} \mathrm{C}_{3}$ & $0.104 c$ & $0.107 d$ & $0.103 d$ & $0.099 \mathrm{~d}$ & $0.093 \mathrm{~d}$ & $0.094 b$ & $0.106 b$ & $0.098 \mathrm{a}-\mathrm{d}$ & $0.091 \mathrm{e}$ & $0.084 \mathrm{e}$ \\
\hline $\mathrm{M}_{2} \mathrm{C}_{4}$ & $0.127 \mathrm{a}$ & $0.124 \mathrm{a}$ & $0.122 \mathrm{a}$ & $0.117 \mathrm{a}$ & $0.112 \mathrm{a}$ & $0.111 b$ & $0.106 b$ & $0.101 \mathrm{abc}$ & $0.100 \mathrm{c}$ & $0.098 b$ \\
\hline $\mathrm{M}_{3} \mathrm{C}_{1}$ & $0.102 \mathrm{c}$ & $0.101 \mathrm{e}$ & $0.098 \mathrm{e}$ & $0.093 \mathrm{e}$ & $0.087 \mathrm{e}$ & $0.104 b$ & $0.100 \mathrm{~cd}$ & $0.087 \mathrm{bcd}$ & $0.085 f$ & $0.054 \mathrm{f}$ \\
\hline $\mathrm{M}_{3} \mathrm{C}_{2}$ & $0.114 b$ & $0.111 \mathrm{c}$ & $0.108 \mathrm{c}$ & $0.103 \mathrm{c}$ & $0.097 \mathrm{c}$ & $0.107 b$ & $0.103 \mathrm{c}$ & $0.087 \mathrm{bcd}$ & $0.087 f$ & $0.081 \mathrm{e}$ \\
\hline $\mathrm{M}_{3} \mathrm{C}_{3}$ & $0.096 \mathrm{~d}$ & $0.094 \mathrm{f}$ & $0.091 \mathrm{f}$ & $0.086 f$ & $0.079 \mathrm{f}$ & $0.086 \mathrm{c}$ & $0.104 \mathrm{c}$ & $0.097 \mathrm{a}-\mathrm{d}$ & $0.090 \mathrm{e}$ & - \\
\hline $\mathrm{M}_{3} \mathrm{C}_{4}$ & $0.116 b$ & $0.113 \mathrm{c}$ & $0.110 \mathrm{c}$ & $0.106 \mathrm{c}$ & $0.100 \mathrm{c}$ & $0.110 \mathrm{~b}$ & $0.103 \mathrm{c}$ & $0.100 \mathrm{a}-\mathrm{d}$ & $0.098 \mathrm{c}$ & $0.095 \mathrm{c}$ \\
\hline $\mathrm{M}_{4} \mathrm{C}_{1}$ & $0.081 \mathrm{~g}$ & $0.080 \mathrm{~h}$ & $0.000 \mathrm{~h}$ & $0.000 \mathrm{~h}$ & $0.000 \mathrm{~h}$ & $0.100 \mathrm{~b}$ & $0.099 \mathrm{~d}$ & $0.084 \mathrm{~cd}$ & $0.084 \mathrm{f}$ & - \\
\hline $\mathrm{M}_{4} \mathrm{C}_{2}$ & $0.084 \mathrm{ef}$ & $0.082 \mathrm{~h}$ & $0.000 \mathrm{~h}$ & $0.000 \mathrm{~h}$ & $0.000 \mathrm{~h}$ & $0.092 b$ & $0.096 \mathrm{e}$ & $0.084 \mathrm{~d}$ & $0.083 \mathrm{f}$ & - \\
\hline $\mathrm{M}_{4} \mathrm{C}_{3}$ & $0.078 \mathrm{~g}$ & $0.076 \mathrm{c}$ & $0.000 \mathrm{~h}$ & $0.000 \mathrm{~h}$ & $0.000 \mathrm{~h}$ & $0.086 \mathrm{c}$ & $0.084 \mathrm{e}$ & $0.080 \mathrm{~d}$ & $0.077 \mathrm{~g}$ & - \\
\hline $\mathrm{M}_{4} \mathrm{C}_{4}$ & $0.088 \mathrm{e}$ & $0.086 \mathrm{~g}$ & $0.082 \mathrm{~g}$ & $0.076 \mathrm{~g}$ & $0.065 \mathrm{~g}$ & $0.109 b$ & $0.103 \mathrm{c}$ & $0.092 \mathrm{a}-\mathrm{d}$ & $0.097 \mathrm{~d}$ & $0.084 \mathrm{e}$ \\
\hline Sign. level & $* *$ & $* *$ & $* *$ & $* *$ & $* *$ & $* *$ & $* *$ & $* *$ & $* *$ & $* *$ \\
\hline CV $(\%)$ & 4.86 & 6.00 & 7.60 & 8.61 & 5.91 & 6.92 & 7.04 & 8.63 & 5.73 & 8.09 \\
\hline
\end{tabular}

DAS= Days after sowing, In a column, values having similar letter(s) do not differ significantly

Note: $\mathrm{C}_{1}=$ Polythene bag, $\mathrm{C}_{2}=$ Plastic pot, $\mathrm{C}_{3}=$ Metallic can, $\mathrm{C}_{4}=$ Glass jar, $\mathrm{M}_{1}=6 \%$ Seed moisture content $(\mathrm{SMC}), \mathrm{M}_{2}=8 \% \mathrm{SMC}, \mathrm{M}_{3}=10 \% \mathrm{SMC}, \mathrm{M}_{4}=12 \% \mathrm{SMC}$, 


\section{Conclusion}

It is concluded that seeds stored in polythene bag or plastic container showed the germination performance similar to those in glass jar. Thus, the study revealed that soybean seed can be stored in polythene bag or plastic pot after drying to 6 to $8 \%$ SMC for retaining high viability.

\section{Reference}

Agha, S. K., Z. H. Malik, M. Hatam and G. H. Jamro. 2004. Emergence of healthy seedlings of soybeans as influenced by seed storage containers. Pakistan J. Biol. Sci. 7(1): 42-44.

Alam, M. M. and M. M. Rahman. 2005. Effect of seed moisture content and thickness of polythene bag on germination and vigour on soybean seed. Bangladesh Seed Sci. Technol. 9(1\& 2): 3338 .

Arulnandhy, V. and Y. D. A. Senanayaka, 1991. Changes in viability, vigour and chemical composition of soybean seeds stored under the humid tropical conditions. Legume Res. 14(3):135-140.

Gomez, K. A. and A. A. Gomez. 1984. Statistical procedures for Agricultural Research $2^{\text {nd }}$ Edn. John Willy and Sons., New York. pp. 97-111.

Hossain, S. M. A. 1978. Storage Environment of Seeds. In: Lecture on Seed Production and Certification. GTI, Bangladesh Agric. Univ. Mymensingh. pp. 87-92.

ISTA (International Seed Testing Association). 1999. International rules for seed testing, 1999. Supplement to Seed Science and Technology. 27: 27-32.

Karim, M. R., M. A. Rahim and G. A. Fakir. 2005. Effect of storage containers on seed quality of onion. Bangladesh J. Seed Sci. Technol. 9(1\&2): 27-31.

Kong, F., S. K. C. Chang, Z. Liu and L. A. Wilson. 2008. Change of soybean quality during storage as related to soyamilk and tofu making. J. Food Sci. 73(3): 134-144.

Krishnappa, A. P., I. A. Adeyemi and O. A. Olorunda. 2002. Effect of processing conditions and packaging material on the quality attributes of groundnut. J. Sci. Food Agric. 82: 1465-1472.

Naznin, H. A., M. S. Monjil, M. A. Kashem, M. R. Islam and J. Hossain. 2005. Quality of wheat seeds stored in different containers. Bangladesh J. Seed Sci. Technol. 9(1\&2): 15-18.

Poonam S., N. Tewari, P. K. Katiyar, T. Das and C.P. Vaish. 2001. Storability of soybean (Glycine $\max$ Merr.) seeds in different containers under ambient conditions. Progres. Agric. 1(1): 9093.

Rahman, M. M., B. Hagidok, M. M. Masood and M. N. Islam. 2010. Effect of storage container and relative humidity on the quality of wheat seed. Bangladesh J. Seed Sci. Technol. 14(1\&2): 89-94.

Samajpati, J. N., M. S. Rahman and T. C. Choudhury. 1978. Comparative study of low cost grain storage structure for domestic use in Bangladesh. Research Report. Department of Agricultural Engineering. Bangladesh Agricultural University, Mymensingh. P. 72.

Simic, B., R. Popovic, A. Sudaric, V. Rozman, T. Kalinovic and J. Cosic. 2007. Influence of storage condition on seed oil content of maize, soybean and sunflower. Agriculturae Conspectus Scientificus Poljoprivredna Znanstvena Smotra. 72(3): 211-213.

Tatipata, A. 2009. Effect of seed moisture content packaging and storage period on microchondria inner membrane of soybean seed. J. Agric. Technol. 5(1): 51-54. 